\title{
Root dry matter mass and distribution of Florico grass under different grazing strategies
}

\author{
Ana Carolina Carvalho de Barros(1), João Carlos de Carvalho Almeida(2), Sergio Trabali Camargo Filho(3), \\ Carlos Augusto Brandão de Carvalho(2), Ludmila Lacerda Campana ${ }^{(4)}$ and Leonardo Fiusa de Morais ${ }^{(5)}$
}

\begin{abstract}
(1)Universidade Federal Rural do Rio de Janeiro (UFRRJ), Instituto de Zootecnia, BR 465, Km 7, CEP 23891-000 Seropédica, RJ, Brazil. E-mail: barros463@gmail.com (2)UFRRJ, Instituto de Zootecnia, BR 465, Km 7, CEP 23891-000 Seropédica, RJ, Brazil. E-mail: joaocarlosbq@gmail.com, carloscarvalho_ufrrj@yahoo.com.br ${ }^{(3)}$ Empresa de Pesquisa Agropecuária do Estado do Rio de Janeiro, Centro Estadual de Pesquisa em Agricultura Orgânica, BR 465, Km 7, CEP 23891-000 Seropédica, RJ, Brazil. E-mail: stcamargo@terra.com.br (4)Escola Estadual Sebastião Cerqueira, Rua Paulo Vieira de Carvalho, no 60, Ilha Lazareto, CEP 36660-000 Além Paraíba, MG, Brazil. E-mail: lacerda.campana@gmail.com ${ }^{(5)}$ Universidade Federal do Ceará, Avenida Mister Hull, № 2.977, CEP 60455-760 Fortaleza, CE, Brazil. E-mail: leonardofiusa@yahoo.com.br
\end{abstract}

\begin{abstract}
The objective of this work was to evaluate the variations in root dry matter mass (RDM) and the percentage distribution (PD) of the root density of Florico grass (Cynodon nlemfuensis) in the 0-40-cm soil layer, when managed under different grazing strategies. Two defoliation frequencies ( 90 and $95 \%$ light interception, as the criterion for allowing animals in the paddock) and two defoliation severities (post-grazing heights of 20 or $30 \mathrm{~cm}$ ) were assessed. Four seasonal evaluations of the root system were performed between the winter of 2012 and the autumn of 2013, using the monolith and trench excavation technique, collecting 1- $\mathrm{dm}^{3}$ samples from soil surface down to a depth of $40 \mathrm{~cm}$, in four sequential extracts of $10 \mathrm{~cm}$ each. Lower RDM values $\left(0.69 \mathrm{~g} \mathrm{dm}^{-3}\right)$ were obtained in winter, with the four grazing strategies, whereas higher values were observed in spring $\left(1.64 \mathrm{~g} \mathrm{dm}^{-3}\right)$, for the $30-\mathrm{cm}$ post-grazing residue, and in autumn $\left(1.63 \mathrm{~g} \mathrm{dm}^{-3}\right)$ for the $20 \mathrm{~cm}$ post-grazing residue, regardless of the light interception value. Between 52 and $66 \%$ of the RDM density was observed in the $10-\mathrm{cm}$ layer, for all four grazing strategies, in all seasons.
\end{abstract}

Index terms: Cynodon nlemfuensis, forage species, light interception, percentage distribution, post-grazing stubble height, root density.

\section{Massa de matéria seca de raízes e distribuição radicular do capim Florico sob diferentes estratégias de pastejo}

\begin{abstract}
Resumo - O objetivo deste trabalho foi avaliar a dinâmica da massa de matéria seca radicular (MSR) e da distribuição percentual (DP) da densidade radicular do capim Florico (Cynodon nlemfuensis), na camada de 0 a 40 $\mathrm{cm}$ de profundidade, sob diferentes estratégias de pastejo. Utilizaram-se duas frequências de desfolha $(90$ e $95 \%$ de interceptação luminosa, como critério para a entrada dos animais em pastejo) e duas severidades de desfolha ( 20 e $30 \mathrm{~cm}$ de resíduo pós-pastejo). Realizaram-se quatro avaliações sazonais no sistema radicular, entre o inverno de 2012 e o outono de 2013, tendo-se utilizado a técnica do monólito com escavação de trincheiras, e retirada de amostras de $1 \mathrm{dm}^{3}$ da superfície do solo até $40 \mathrm{~cm}$ de profundidade, em quatro extratos sequenciais de $10 \mathrm{~cm}$ de profundidade cada um. Menores valores de $\operatorname{MSR}\left(0.69 \mathrm{~g} \mathrm{dm}^{-3}\right)$ foram obtidos no inverno, nas quatro estratégias de pastejo, e os maiores na primavera $\left(1.64 \mathrm{~g} \mathrm{dm}^{-3}\right)$, para $30 \mathrm{~cm}$ de resíduo pós-pastejo, e no outono $\left(1.63 \mathrm{~g} \mathrm{dm}^{-3}\right)$ para $20 \mathrm{~cm}$ de resíduo pós-pastejo, independentemente da interceptação luminosa adotada. Entre 52 e $66 \%$ da densidade de MSR foi observada na camada de $0-10 \mathrm{~cm}$, nas quatro estratégias de pastejo, em todas as estações do ano.
\end{abstract}

Termos para indexação: Cynodon nlemfuensis, espécies forrageiras, interceptação luminosa, distribuição percentual, altura de resíduo pós-pastejo, densidade radicular.

\section{Introduction}

Pastures occupy approximately one-quarter of the Brazilian territory and are the cheapest food source for ruminants. In the search for highly productive forage species for ruminant feed, the grasses of the genus Cynodon have been focused on because of their versatility and flexibility in use (Carvalho et al., 2012).

Florico grass (Cynodon nlemfuensis Vanderyst 'Florico') (ex. Puerto Rico Star grass) has emerged as a suitable species for grazing when grown under suitable management and fertilization conditions (Pedreira, 
2010). Florico grass is highly productive and it adapts to different climate and soil conditions; therefore, it is more resistant to changes in the employed management practices (Rodrigues Filho et al., 2000).

The genus Cynodon originated in East Africa. Cynodon nlemfuensis or star grass shows more developed stolons and fewer rhizomes than other Cynodon species. It is a rustic, persistent plant that is adapted to different climatic conditions (Pedreira, 2010); however, it has a higher fertility requirement than other grasses.

In general, studies of forage plants focus on aerial shoots but lack information on the root system (Monteiro \& Consolmagno Neto, 2008; Silveira \& Monteiro, 2011). However, the root system, which is the source of carbohydrates and proteins for the early stages of grass regrowth, interacts with the aerial shoot, which is responsible for the development of the plant (Ribeiro et al., 2011), particularly under grazing conditions. Therefore, after defoliation by grazing, physiologically distinct effects are observed. There is a transition period during which the organic reserves are used for quick restoration of tissues lost because of herbivory and a subsequent period in which physiological activity is adjusted as the stocks of reserves are gradually restored (Rodrigues et al., 2007; Ribeiro et al., 2011).

Defoliation is known to be required for the renewal of the aerial shoots of plants; therefore, the frequency and severity of grazing should encourage the maintenance of a strong and deep root system that can help reduce the plant regrowth time. Forages with a strong and deep root system support different grazing strategies; such a root system also increases the resistance of these grasses to stress caused by severe winters, dry summers, and grazing itself (Cunha et al., 2010), and increases their competitive nutrient uptake (Monteiro \& Consolmagno Neto, 2008; Kaiser et al., 2009).

In this context, it is difficult to design pasture management strategies that increase the intensity and/ or frequency of grazing without reducing the root dry matter mass reserve (Rodrigues et al., 2007; Sarmento et al., 2008; Kaiser et al., 2009). The effective depth of the root system of Florico grass under grazing was found to be $35 \mathrm{~cm}$ by Cunha et al. (2010), whereas Camargo Filho (2007) showed that $85 \%$ of the roots were found at a depth of $40 \mathrm{~cm}$. However, the effect of grazing strategies on the density and percentage distribution of the root system of the Florico grass is not observed in the effective layer, where there is a higher concentration of roots (soil surface down to $40-\mathrm{cm}$ depth); the effect of grazing on the seasonality of this species also remains unclear.

The objective of this work was to evaluate the variations in root dry matter mass (RDM) and the percentage distribution (PD) of the root density of Florico grass in the $0-40$-cm soil layer, when managed under different grazing strategies.

\section{Materials and Methods}

The experiment was conducted in the experimental field of Centro Estadual de Pesquisa em Agricultura Orgânica of Empresa de Pesquisa Agropecuária do Estado do Rio de Janeiro, in the municipality of Seropédica, in the state of Rio de Janeiro, Brazil $\left(22^{\circ} 47^{\prime} \mathrm{S}, 43^{\circ} 40^{\prime} \mathrm{W}\right.$, at an altitude of $\left.31 \mathrm{~m}\right)$. The climate of the region is tropical rainy, of the savannah subtype Aw, according to Köppen's classification, characterized by the annual distribution of rainfall. There is a dry period during the colder months, which extends from April to September (fall and winter), and a rainy period during the warmer months from October to March (spring and summer). Data on the rainfall and average temperature, used to calculate the water balance (Table 1), were recorded by the meteorological station Ecologia Agrícola, located approximately 1,500 m from the site of the experiment; these data showed that, in 2012, a water deficit was expected for the fall/ winter period and during most of spring.

The soil was classified as a Argissolo VermelhoAmarelo (Santos et al., 2013), i.e., an Ultisol, based on the chemical characterization of the $0-20-\mathrm{cm}$ layer in 2011: pH H20 (1:2.5) 6.0, $59.3 \mathrm{mg} \mathrm{dm}^{-3} \mathrm{P}$ (Mehlich-1), $0.6 \mathrm{cmol}_{\mathrm{c}} \mathrm{dm}^{-3} \mathrm{~K}, 2.5 \mathrm{cmol}_{\mathrm{c}} \mathrm{dm}^{-3} \mathrm{Ca}, 0.7 \mathrm{cmol}_{\mathrm{c}} \mathrm{dm}^{-3} \mathrm{Mg}$, $2.8 \mathrm{cmol}_{\mathrm{c}} \mathrm{dm}^{-3} \mathrm{H}+\mathrm{Al}$, sum of bases of $3.8 \mathrm{cmol}_{\mathrm{c}} \mathrm{dm}^{-3}$, cation exchange capacity of $6.6 \mathrm{cmol}_{\mathrm{c}} \mathrm{dm}^{-3}$, bases saturation of $58 \%, 2.3 \mathrm{~g} \mathrm{~kg}^{-1}$ soil organic matter, and $13.0 \mathrm{~g} \mathrm{~kg}^{-1}$ organic carbon.

The experiment was conducted in a 0.48 -ha Florico grass pasture established in 2008, consisting of 16 paddocks (experimental units), with dimensions of $15 \times 20 \mathrm{~m}\left(300 \mathrm{~m}^{2}\right)$. Pasture management consisted of four treatments (pasture strategy), corresponding to the combination of two frequencies of defoliation and two defoliation severities, which were allocated 
to the paddocks in a $2 \times 2$ factorial arrangement in a randomized complete block design, with four replicates per treatment. Defoliation frequency was controlled using thresholds of 90 and $95 \%$ light interception (LI) as a criterion for allowing animals to enter the paddocks, whereas defoliation severities corresponded to 20 - or $30-\mathrm{cm}$ post-grazing residue (PGR). The four different treatments were labeled 90-20, 90-30, 95-20, and 95-30. Grazing by non-breastfeeding cows and crossbred heifers (Holstein x Zebu cows) was allowed from January 2012 to June 2013, for an average period of 48 hours; four to seven animals were used per replicate depending on forage availability.

Fertility management of the grazing strategies using nutrients consisted of nitrogen fertilization equivalent to $200 \mathrm{~kg} \mathrm{~N}$ and $160 \mathrm{~kg} \mathrm{ha}^{-1} \mathrm{~K}_{2} \mathrm{O}$ per year, in the form of urea and potassium chloride, respectively. For each pasture strategy, the nutrients were generally applied two weeks after the last cycle of grazing for each grazing season (Table 2).

Table 1. Climatic data and water balance (WB) observed during the grazing period from January 2012 to June 2013.

\begin{tabular}{|c|c|c|c|c|}
\hline \multirow[t]{2}{*}{ Month/Year } & \multicolumn{2}{|c|}{ Temperature $\left(\mathrm{C}^{\circ}\right)^{(1)}$} & \multirow{2}{*}{$\begin{array}{l}\text { Cumulative } \\
\text { rainfall }(\mathrm{mm})\end{array}$} & \multirow{2}{*}{$\begin{array}{l}\mathrm{WB}^{(2)} \\
(\mathrm{mm})\end{array}$} \\
\hline & Maximum & Minimum & & \\
\hline January 2012 & 29.9 & 21.4 & 298.0 & 191.39 \\
\hline February 2012 & 33.9 & 22.0 & 42.6 & -132.12 \\
\hline March 2012 & 31.6 & 20.7 & 0.0 & -138.64 \\
\hline April 2012 & 29.3 & 20.6 & 64.6 & -36.79 \\
\hline May 2012 & 26.7 & 16.9 & 55.8 & -25.93 \\
\hline June 2012 & 26.2 & 17.1 & 103.0 & 27.87 \\
\hline July 2012 & 26.4 & 16.9 & 32.6 & -45.93 \\
\hline August 2012 & 27.3 & 15.7 & 31.4 & -63.66 \\
\hline September 2012 & 28.4 & 17.5 & 77.6 & -25.87 \\
\hline October 2012 & 31.1 & 20.0 & 63.2 & -69.40 \\
\hline November 2012 & 27.7 & 20.3 & 101.2 & 21.02 \\
\hline December 2012 & 34.4 & 23.3 & 138.6 & -38.49 \\
\hline January 2013 & 29.9 & 21.8 & 363.2 & 259.14 \\
\hline February 2013 & 33.5 & 23.0 & 172.2 & 11.04 \\
\hline March 2013 & 30.1 & 20.7 & 185.8 & 73.67 \\
\hline April 2013 & 28.5 & 18.5 & 92.2 & -7.18 \\
\hline May 2013 & 27.5 & 16.5 & 92.2 & -2.24 \\
\hline June 2013 & 27.4 & 16.9 & 27.0 & -64.68 \\
\hline
\end{tabular}

${ }^{(1)}$ Monthly average. ${ }^{(2)}$ Positive values indicate excess water, and negative values indicate monthly water deficits. Source: National Institute of Meteorology, Agricultural Ecology Station in Seropédica, RJ (INMET, 2017)
Table 2. Period (days) of grazing cycles, fertilizer application dates, and root evaluation in four grazing strategies of Florico grass (Cynodon nlemfuensis).

\begin{tabular}{|c|c|c|c|c|c|}
\hline \multirow[t]{2}{*}{ Season } & \multicolumn{3}{|c|}{ Grazing cycle } & \multirow{2}{*}{$\begin{array}{l}\mathrm{N} \text { and } \mathrm{K} \\
\text { fertilization } \\
\text { (date) }\end{array}$} & \multirow{2}{*}{$\begin{array}{c}\text { Root } \\
\text { evaluation } \\
\text { (date) }\end{array}$} \\
\hline & Start (date) & End (date) & Period & & \\
\hline & \multicolumn{5}{|c|}{$90 \%$ light interception (LI) - $20 \mathrm{~cm}$ post-grazing residue (PGR) } \\
\hline \multirow{3}{*}{ Summer 2012} & Jan. 2 & Jan. 30 & 28 & - & - \\
\hline & Jan. 30 & Mar. 1 & 31 & - & - \\
\hline & Mar. 1 & Apr. 2 & 32 & Apr. 16 & - \\
\hline \multirow{2}{*}{ Fall,2012 } & Apr. 2 & May 7 & 35 & - & - \\
\hline & May 7 & July 2 & 56 & July 16 & - \\
\hline \multirow{2}{*}{ Winter 2012} & July 2 & Aug. 14 & 43 & - & Aug. $21^{(1)}$ \\
\hline & Aug. 14 & Sept. 23 & 40 & Oct. 7 & - \\
\hline \multirow{2}{*}{ Spring 2012} & Sept. 23 & Oct. 29 & 36 & - & - \\
\hline & Oct. 29 & Dec. 5 & 37 & Dec. 19 & Dec. 12 \\
\hline \multirow{3}{*}{ Summer 2013} & Dec. 5 & Jan. 10 & 36 & - & - \\
\hline & Jan. 10 & Feb. 5 & 26 & - & - \\
\hline & Feb. 5 & Mar. 1 & 24 & Mar. 15 & Mar. 8 \\
\hline \multirow{2}{*}{ Fall 2013} & Mar. 1 & Apr. 18 & 48 & - & - \\
\hline & Apr. 18 & June 1 & 44 & June 15 & June 8 \\
\hline & \multicolumn{5}{|c|}{$90 \%$ light interception (LI) - $30 \mathrm{~cm}$ post-grazing residue (PGR) } \\
\hline \multirow{3}{*}{ Summer 2012} & Jan. 12 & Feb. 4 & 23 & - & - \\
\hline & Feb. 4 & Feb. 29 & 25 & - & - \\
\hline & Feb. 29 & Mar. 26 & 26 & Apr. 9 & - \\
\hline \multirow{2}{*}{ Fall 2012} & Mar. 26 & Apr. 24 & 29 & - & - \\
\hline & Apr. 24 & June 15 & 52 & June 29 & - \\
\hline \multirow{3}{*}{ Winter 2012} & June 15 & July 21 & 36 & - & - \\
\hline & July 21 & Aug. 29 & 39 & - & Sept. 5* \\
\hline & Aug. 29 & Oct. 7 & 39 & Oct. 21 & - \\
\hline \multirow{2}{*}{ Spring 2012} & Oct. 7 & Nov. 17 & 41 & - & - \\
\hline & Nov. 17 & Dec. 19 & 32 & Jan. 2 & Dec. 26 \\
\hline \multirow{4}{*}{ Summer 2013} & Dec. 19 & Jan. 10 & 22 & - & - \\
\hline & Jan. 10 & Jan. 31 & 21 & - & - \\
\hline & Jan. 31 & Feb. 19 & 19 & - & - \\
\hline & Feb. 19 & Mar. 11 & 20 & Mar. 25 & Mar. 18 \\
\hline Fall 2013 & Mar. 11 & Apr. 19 & 39 & - & - \\
\hline rall 2013 & Apr. 19 & June 2 & 44 & June 16 & June 9 \\
\hline & $95 \%$ light in & erception (L & $20 \mathrm{~cm} \mathrm{p}$ & st-grazing res & due (PGR) \\
\hline Summer 2012 & Dec. 30 & Jan. 30 & 31 & - & - \\
\hline & Jan. 30 & Mar. 5 & 35 & Mar. 19 & - \\
\hline & Mar. 5 & Apr. 8 & 34 & - & - \\
\hline Fall 2012 & Apr. 8 & May 17 & 39 & - & - \\
\hline & May 17 & July 17 & 61 & July 31 & - \\
\hline Winter 2012 & July 17 & Oct. 8 & 83 & Oct. 22 & Oct. 15 \\
\hline Spring 2012 & Oct. 8 & Nov. 28 & 51 & Dec. 12 & Dec. 5 \\
\hline & Nov. 28 & Jan. 2 & 35 & - & - \\
\hline Summer 2013 & Jan. 2 & Feb. 10 & 39 & - & - \\
\hline & Feb. 10 & Mar. 12 & 30 & Mar. 28 & Mar. 19 \\
\hline Fall 2013 & Mar. 12 & Apr. 28 & 47 & - & - \\
\hline 1 dint 2010 & Apr. 28 & June 18 & 51 & July 2 & June 25 \\
\hline & $95 \%$ light in & erception (L & $30 \mathrm{~cm}$ & st-grazing res & due (PGR) \\
\hline Summer 2012 & Jan. 28 & Feb 28 & 31 & - & - \\
\hline summint 2012 & Feb. 28 & Apr. 4 & 36 & Apr. 18 & - \\
\hline Fall 2012 & Apr. 4 & May 19 & 45 & June 2 & - \\
\hline Winter 2012 & May 19 & July 23 & 65 & - & - \\
\hline willer 2012 & July 23 & Oct. 17 & 86 & Oct. 31 & Oct. 24 \\
\hline Snring 2012 & Oct. 17 & Dec. 5 & 49 & Dec. 19 & Dec. $12^{*}$ \\
\hline sping 2012 & Dec. 5 & Jan. 3 & 29 & - & - \\
\hline Summer 2013 & Jan. 3 & Feb. 3 & 31 & - & - \\
\hline 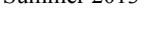 & Feb. 3 & Mar. 3 & 28 & Mar. 17 & Mar. 10 \\
\hline Fall 2013 & Mar. 3 & Apr. 22 & 50 & - & - \\
\hline & Apr. 22 & June 19 & 58 & July 3 & June 26 \\
\hline
\end{tabular}


The monitoring of LI by the forage canopy was performed at 20 random points per paddock, once a week between 11:00 a.m. and 01:00 p.m. When the average LI of four replicates of the same treatment reached 85 and $90 \%$ in the 90 and $95 \%$ LI treatments, respectively, monitoring was subsequently done twice a week. Each point represented the mean of two readings above the forage canopy, through a single sensor and two measures close to the ground, using a bar of 80 sensors, placed in the north-south direction in the first measurement and in the east-west direction in the second measurement. All measurements were performed with the AccuPAR LP-80 Linear PAR/ LAI Ceptometer (Decagon Devices, Inc., Pullman, WA, USA). Grazing animals were allowed to enter the pastures when the mean of four experimental units achieved the desired light interception for each treatment, i.e., 90 or $95 \% \mathrm{LI}$.

Forage mass was measured by cutting samples close to the ground. Immediately after harvesting the forage, samples of four $0.25-\mathrm{m}^{2}$ rims per experimental unit were divided into stem + pseudostem, leaf blade, and dead material. These components were weighed, and the leaf blades were passed through a scanner to determine LI. All the fractions were dried immediately after fractionation in a forced-air circulation oven at $55^{\circ} \mathrm{C}$ until they reached a constant weight.

The height of the pasture was evaluated on the same dates as LI was monitored, between 09:00 a.m. and 11:00 a.m., at 40 random points per experimental unit, using a ruler graduated in millimeters and a sheet of acetate, according to the methodology described by Carnevalli \& Silva (1999).

Monitoring of PGR height began after 24 hours of grazing and was repeated every 4 hours until the mean of each paddock reached the recommended PGR height. The animals were removed from the paddock and, when necessary, rearranged across other replicates that had not yet reached the desired residue height, i.e., 20- or 30-cm PGR.

To estimate the RDM reserve and the PD of root density for each pasture strategy, two trenches were dug $(0.5 \times 0.4 \times 0.6 \mathrm{~m})$ for each replicate, 1 week after the grazing cycle, for each season of the year. For the pasture strategies $90-0.2,90-0.3,95-0.2$, and 95-0.3, respectively, samples were taken in: winter, on August 21, September 5, October 15, and October 24, 2012; spring, on December 12, December 26, December 5, and December 12, 2012; summer, on March 8, March 18, March 19, and March 10, 2013; and fall, on June 8, June 9, June 25, and June 26, 2013. Samples were taken at four depths: $0.0-0.1,0.1-0.2,0.2-0.3$, and $0.3-0.4 \mathrm{~m}$, using an iron monolith $(0.1 \times 0.2 \times 0.05 \mathrm{~m})$. The grazing cycle, rest period, and root evaluation dates are shown in Table 2.

After the collection of soil + root samples, the trenches were closed and samples were collected at another location in the paddock. Collected samples were placed in 10-L buckets, and the visible roots were collected manually and deposited on sieves with 4-, 2-, and 1-mm mesh under a gentle stream of water. Next, flowing water was added to the bucket and the whole mass (soil + roots) was agitated to suspend the remaining roots and root fragments. The suspension was then sieved until all visible roots were separated, according to the method described by Camargo Filho (2007) with some modifications. After the samples were prepared, the roots were weighed on an analytical scale and placed in an oven at $\pm 60^{\circ} \mathrm{C}$ with forced air circulation for 72 hours, until they reached a constant weight.

The variables were grouped by the time of year - winter, spring, summer, and fall - and subjected to two-way analysis of variance using the GraphPad Prism5 statistical package (GraphPad Software Inc., San Diego, CA, USA). Plots were arranged divided by time, with the grazing strategies as the plots and the seasons of the year as the subplots. To compare the means of the main effects, i.e., LI and PGR, and identify significant interactions, the Bonferroni test, at $5 \%$ probability, was used. For the PD (\%) in depth, the regression analysis (exponentially with plateau) was performed, and equations were compared using the F-test.

\section{Results and Discussion}

Variations in RDM and PD of the root density of Florico grass, managed using four different pasture strategies, were consistent with the management strategy applied to the shoots because of the close relationship between the aerial and the underground components of pasture growth, where the root is the source of energy and the shoot is a drain on the organic reserves (Rodrigues et al., 2007; Silva et al., 2015). To establish a relationship between the effects occurring in the aerial part of the plant and the root system, variables such as pre-grazing pasture height,

Pesq. agropec. bras., Brasília, v.52, n.12, p.1276-1285, dez. 2017 DOI: 10.1590/S0100-204X2017001200017 
accumulation of forage mass, and the LAI were analyzed.

The pre-grazing canopy height was affected by the LI in the spring, with greater heights observed at $95 \%$ LI in treatments with a PGR of 20 or $30 \mathrm{~cm}$ (Table 3). In winter, a greater canopy height was observed at $95 \%$ LI with a PGR of $30 \mathrm{~cm}$; similarly, in summer, a greater canopy height was observed at $95 \%$ LI but with a PGR of $20 \mathrm{~cm}$. In fall, different management strategies did not result in different canopy heights.

The absence of a positive association between canopy height and LI observed in this study, based on the results gathered in fall and supported by the results for winter and summer, may be related to the prostrate growth habit of this species. In cespitose grasses of the genera Panicum and Brachiaria, positive associations have been reported between canopy height and LI throughout the year (Carnevalli et al., 2006; Barbosa et al., 2007; Pedreira et al., 2007; Zanine et al., 2011).

Conversely, the obtained results showed that the height of the canopy was affected by a PGR height of $20 \mathrm{~cm}$ in winter and $30 \mathrm{~cm}$ in summer at $90 \% \mathrm{LI}$ (Table 3). This inversion of a greater PGR height in summer compared with winter can be associated with the duration of the grazing cycles of Florico grass at these times of the year.

In winter, the 90-20 strategy had a cycle of 43 days, preceded by a cycle of 56 days, whereas the 90-30 strategy had a cycle of 39 days, preceded by a cycle of 36 days (Table 2). This 20-day difference in the length of the previous grazing cycle in unfavorable growing seasons (Table 1) favored stem elongation, resulting in greater canopy heights for the 90-20 strategy.

In summer, the grazing cycles were 24 and 20 days, and previous cycles were 26 and 19 days, respectively, for the 90-20 and 90-30 strategies (Table 2). This favorable growth time (Table 1) and higher PGR height resulted in a greater pre-grazing canopy height. The obtained results also showed that the grazing strategies resulted in rest periods for the Florico grass. Several authors have reported the rest period of this genus to be approximately 27 to 30 days (Vilela et al., 2005; Costa et al., 2013; Soriano et al., 2013), using other grazing strategies such as fixed resting interval and canopy height.

The pre-grazing forage mass varied according to the increase in the level of LI in summer; in spring, PGRs of $30 \mathrm{~cm}$ were recorded in the grazing strategies with 95\% LI (Table 3), with a greater forage availability observed for the 95-30 strategy in spring and the 95-20 strategy in Summer.

Increases in the level of LI increased the leaf area index (LAI) in all seasons of the year except for winter when the height of the PGR negatively affected the LAI with higher levels of LI (Table 4). The positive association between LAI and LI partially verified in this study has also been reported in grasses of the genus Brachiaria (Braga et al., 2006).

The RDM was higher in spring in the grazing strategies with a lower severity of defoliation $(30-\mathrm{cm}$ PGR), 1.60 and $1.67 \mathrm{~g} \mathrm{dm}^{-3}$, respectively, for 90 and $95 \%$ LI. For the strategies with the more severe defoliation (20-cm PGR), the highest RDM densities were observed in summer $\left(1.48 \mathrm{~g} \mathrm{dm}^{-3}\right)$ and fall $\left(1.64 \mathrm{~g} \mathrm{dm}^{-3}\right)$ for $90 \%$ LI and in fall $\left(1.62 \mathrm{~g} \mathrm{dm}^{-3}\right)$ for $95 \%$ LI. In all grazing strategies, lower values were observed in winter than in the other seasons (Table 5). In Coast cross grass, Ribeiro et al. (2011) reported higher RDM density in the fall than in summer and winter, leading these authors to hypothesize that the accumulation of RDM is a plant

Table 3. Effect of the pre-grazing conditions (PGR) on canopy height and on dry matter accumulation of Florico grass (Cynodon nlemfuensis) throughout the year, with four different grazing strategies ${ }^{(1)}$.

\begin{tabular}{|c|c|c|c|c|c|c|c|c|}
\hline \multirow{2}{*}{$\begin{array}{l}\text { Light interception } \\
(\%)\end{array}$} & \multicolumn{2}{|c|}{ Winter 2012 PGR (cm) } & \multicolumn{2}{|c|}{ Spring 2012 PGR $(\mathrm{cm})$} & \multicolumn{2}{|c|}{ Summer 2013 PGR (cm) } & \multicolumn{2}{|c|}{ Fall 2013 PGR (cm) } \\
\hline & 20 & 30 & 20 & 30 & 20 & 30 & 20 & 30 \\
\hline & \multicolumn{8}{|c|}{ Canopy height $(\mathrm{cm})$} \\
\hline 90 & 41.6Aa & $36.9 \mathrm{Bb}$ & $47.1 \mathrm{Ab}$ & $41.2 \mathrm{Ab}$ & $56.6 \mathrm{Bb}$ & $62.0 \mathrm{Aa}$ & $52.7 \mathrm{Aa}$ & $50.8 \mathrm{Aa}$ \\
\hline \multirow[t]{2}{*}{95} & $42.5 \mathrm{Aa}$ & $45.2 \mathrm{Aa}$ & $51.5 \mathrm{Aa}$ & $44.5 \mathrm{Aa}$ & $65.2 \mathrm{Aa}$ & 63.9Aa & $54.6 \mathrm{Aa}$ & $54.5 \mathrm{Aa}$ \\
\hline & \multicolumn{8}{|c|}{ Forage dry matter accumulation $\left(\mathrm{g} \mathrm{m}^{-2}\right.$ per cycle) } \\
\hline 90 & $180 \mathrm{Ab}$ & $162 \mathrm{Aa}$ & $172 \mathrm{Aa}$ & $157 \mathrm{Ab}$ & $162 \mathrm{Ab}$ & $166 \mathrm{Ab}$ & $135 \mathrm{Aa}$ & $152 \mathrm{Aa}$ \\
\hline 95 & $223 \mathrm{Aa}$ & $131 \mathrm{Bb}$ & $179 \mathrm{Ba}$ & $218 \mathrm{Aa}$ & $193 \mathrm{Aa}$ & $190 \mathrm{Aa}$ & $134 \mathrm{Aa}$ & $118 \mathrm{Ab}$ \\
\hline
\end{tabular}

(1)Means followed by equal letters, uppercase in the rows and lowercase in the columns, do not differ significantly in the same season by Bonferroni's test, at 5\% probability. LI, light interception; and PGR, height of the post-grazing residue. 
physiological response, in which the root mass is increased to store more non-structural carbohydrates to be used at another time.

With more severe defoliation, an increase in the RDM density was observed over time, with maximum values found in fall; this suggests that this is a physiological response of the plant to accumulate organic reserves for survival during winter. The seasonal change in the RDM density was similar to the results presented by Cunha et al. (2010), who reported an RDM density of approximately $0.6 \mathrm{~g} \mathrm{dm}^{-3}$ in star grass (C. nlemfuensis) under fertilized grazing conditions with both 100 or $300 \mathrm{~kg} \mathrm{~N} \mathrm{ha}^{-1}$ per year, and by Ribeiro et al. (2011), who also reported higher RDM densities in fall.

In the management strategies with less severe defoliation (30-cm PGR), the recovery of the organic reserves in the roots occurred only in spring (Table 5). This indicates the importance of the root system

Table 4. Effect of the pre-grazing conditions on the canopy height index of Florico grass (Cynodon nlemfuensis) throughout the year, with four different grazing strategies ${ }^{(1)}$.

\begin{tabular}{lcccc}
\hline Grazing strategy & $\begin{array}{c}\text { Winter } \\
2012\end{array}$ & $\begin{array}{c}\text { Spring } \\
2012\end{array}$ & $\begin{array}{c}\text { Summer } \\
2013\end{array}$ & $\begin{array}{c}\text { Fall } \\
2013\end{array}$ \\
\hline $90 \mathrm{LI}-20 \mathrm{PGR}$ & $2.68 \mathrm{Cc}$ & $3.67 \mathrm{Bb}$ & $4.46 \mathrm{Ad}$ & $3.76 \mathrm{Bc}$ \\
$90 \mathrm{LI}-30 \mathrm{PGR}$ & $2.98 \mathrm{BCbc}$ & $2.84 \mathrm{Cc}$ & $4.60 \mathrm{Ac}$ & $3.60 \mathrm{Bd}$ \\
$95 \mathrm{LI}-20 \mathrm{PGR}$ & $3.40 \mathrm{Cb}$ & $4.56 \mathrm{Ba}$ & $5.68 \mathrm{Aa}$ & $4.79 \mathrm{Ba}$ \\
$95 \mathrm{LI}-30 \mathrm{PGR}$ & $3.79 \mathrm{BCa}$ & $3.66 \mathrm{Cb}$ & $5.59 \mathrm{Ab}$ & $4.44 \mathrm{Bb}$ \\
\hline
\end{tabular}

${ }^{(1)}$ Means followed by equal letters, uppercase in the rows and lowercase in the columns, do not differ significantly in the same season by Bonferroni's test, at 5\% probability. LI, light interception; and PGR, height of the postgrazing residue.

Table 5. Root dry matter mass densities $\left(\mathrm{g} \mathrm{dm}^{-3}\right)$ of Florico grass (Cynodon nlemfuensis) grown under four different grazing strategies ${ }^{(1)}$.

\begin{tabular}{lcccc}
\hline \multirow{2}{*}{ Season } & \multicolumn{4}{c}{ Grazing strategy (LI-PGR) } \\
\cline { 2 - 5 } & $90-20$ & $90-30$ & $95-20$ & $95-30$ \\
\hline Winter 2012 & $0.63 \mathrm{Ab}$ & $0.76 \mathrm{Ab}$ & $0.76 \mathrm{Ab}$ & $0.60 \mathrm{Ab}$ \\
Spring 2012 & $1.25 \mathrm{ABab}$ & $1.60 \mathrm{Aa}$ & $1.04 \mathrm{Bab}$ & $1.67 \mathrm{Aa}$ \\
Summer 2013 & $1.48 \mathrm{Aa}$ & $1.10 \mathrm{Aab}$ & $1.25 \mathrm{Aab}$ & $1.26 \mathrm{Aab}$ \\
Fall 2013 & $1.64 \mathrm{Aa}$ & $0.99 \mathrm{Aab}$ & $1.62 \mathrm{Aa}$ & $1.03 \mathrm{Aab}$ \\
\hline
\end{tabular}

(1) Means followed by equal letters, uppercase in the rows and lowercase in the columns, do not differ significantly in the same season by Bonferroni's test, at $5 \%$ probability. LI, light interception; and PGR, height of the pos-grazing residue. in the accumulation of organic reserves. In stalk grasses, however, rhizomes also play a key role in the accumulation of organic reserves (Rodrigues et al., 2007; Mueller et al., 2013; Plaza-Bonilla et al., 2014; Silva et al., 2015). RDM densities similar to the highest values observed in spring and fall in this study $\left(1.69 \mathrm{~g} \mathrm{dm}^{-3}\right)$ have previously been reported in Urochloa brizantha 'Marandu' during the rainy period (Santos et al., 2007), and in P. maximum 'Milênio' fertilized with $150 \mathrm{~kg} \mathrm{ha}^{-1} \mathrm{~N}$ per year (Sarmento et al., 2008).

No relationships were observed between the parameters of the aerial part of the plant (pre-grazing canopy height, the accumulation of forage mass, and LAI) and the root mass density.

No significant differences were found between the RDM densities of the different grazing strategies in the winter of 2012, and the summer and fall of 2013 (Table 6), possibly because of the high variability of the data, i.e., coefficient of variation $(\mathrm{CV}) \geq 75 \%$. These results confirm that the root system density varies homogeneously according to water and nutrient availability (Costa et al., 2002; Mueller et al., 2013; Plaza-Bonilla et al., 2014).

According to Rodrigues et al. (2007) and Silva et al. (2015), during the rainy period, the sink-source mechanism results in the fast recovery of the aerial parts of the plant, after which the organic reserves are redirected to restore the root system reserves. In fact, in the spring of 2012, when the hydric balance was positive in November (Table 1), the treatments with less severe defoliation (90-30 and 95-30) accumulated higher RDM densities (1.60 and $1.67 \mathrm{~g} \mathrm{dm}^{-3}$ ) than the 95-20 treatment $\left(1.04 \mathrm{~g} \mathrm{dm}^{-3}\right)$ (Table 5); this may be explained by the greater disruption caused by herbivory that occurred in the grazing strategies with more severe defoliation.

Table 6. Root dry matter mass density (RDM) of Florico grass (Cynodon nlemfuensis) as a function of soil depth.

\begin{tabular}{lcc}
\hline Season & Equation & $\mathrm{R}^{2}$ \\
\hline Winter 2012 & $\mathrm{RDM}=2.47 \mathrm{e}^{-12.94(\text { depth })}+0.26$ & 0.89 \\
Spring 2012 & $\mathrm{RDM}(90-0.3$ and $95-0.3)=6.69 \mathrm{e}^{-11.98(\text { depth })}+0.34$ & 0.89 \\
& $\mathrm{RDM}(95-0.2)=3.34 \mathrm{e}^{-9.19(\text { depth })}+0.19$ & 0.89 \\
Summer and & $\mathrm{RDM}=5.55 \mathrm{e}^{-14.52(\text { depth })}+0.42$ & 0.86 \\
Autumn 2013 & & \\
\hline
\end{tabular}

(1) Depth $=0.05,0.15,0.25$, or $0.35 \mathrm{~m}$.

Pesq. agropec. bras., Brasília, v.52, n.12, p.1276-1285, dez. 2017 DOI: 10.1590/S0100-204X2017001200017 
In addition to the effect of grazing strategies on the RDM density, knowledge of the trend of the PD of RDM along the profile of the superficial soil layer allows infering about the ability of the plant to acquire water and nutrients (Costa et al., 2002; Mueller et al., 2013; Plaza-Bonilla et al., 2014). This concentration of roots near soil surface is explained by the branched architecture of the root system, common in forage grasses (Santos et al., 2007; Sarmento et al., 2008; Ribeiro et al., 2011). The highest concentrations of roots were observed in the $0-10-\mathrm{cm}$ layer (51.8 to $65.6 \%$ ) for all four grazing strategies in all seasons (Table 7).

The accumulation of RDM in the soil surface layer has also been reported previously by Ribeiro et al. (2011) in pastures of Coast cross grass intercropped

Table 7. Percentage distribution of root dry matter mass ( $\%)$ of Florico grass (Cynodon nlemfuensis) as a function of the soil depth profile ${ }^{(1)}$.

\begin{tabular}{lcccc}
\hline \multirow{2}{*}{$\begin{array}{l}\text { Profile } \\
(\mathrm{cm})\end{array}$} & \multicolumn{4}{c}{ Grazing strategy (LI-PGR) } \\
\cline { 2 - 5 } & $90-20$ & $90-30$ & $95-20$ & $95-30$ \\
\hline \multirow{5}{c}{ Winter 2012} \\
$0-10$ & $53.8 \mathrm{Aab}$ & $57.7 \mathrm{Aa}$ & $53.0 \mathrm{Aa}$ & $60.2 \mathrm{Aab}$ \\
$10-20$ & $21.7 \mathrm{Ba}$ & $21.4 \mathrm{Ba}$ & $22.4 \mathrm{Ba}$ & $18.1 \mathrm{Ba}$ \\
$20-30$ & $16.4 \mathrm{BCa}$ & $11.9 \mathrm{BCa}$ & $15.1 \mathrm{BCa}$ & $14.0 \mathrm{Ba}$ \\
$30-40$ & $8.1 \mathrm{Ca}$ & $9.0 \mathrm{Ca}$ & $9.6 \mathrm{Ca}$ & $7.7 \mathrm{Ba}$ \\
\hline & \multicolumn{5}{c}{ Spring 2012} \\
$0-10$ & $61.0 \mathrm{Aab}$ & $56.2 \mathrm{Aa}$ & $55.8 \mathrm{Aa}$ & $65.5 \mathrm{Aa}$ \\
$10-20$ & $22.2 \mathrm{Ba}$ & $24.2 \mathrm{Ba}$ & $24.6 \mathrm{Ba}$ & $21.1 \mathrm{Ba}$ \\
$20-30$ & $10.2 \mathrm{Ca}$ & $11.5 \mathrm{Ca}$ & $11.6 \mathrm{Ca}$ & $7.9 \mathrm{Ca}$ \\
$30-40$ & $8.6 \mathrm{Ca}$ & $8.1 \mathrm{Ca}$ & $8.0 \mathrm{Ca}$ & $5.5 \mathrm{Ca}$ \\
\hline & \multicolumn{5}{c}{$\mathrm{Summer} 2013$} \\
$0-10$ & $65.6 \mathrm{Aa}$ & $64.9 \mathrm{Aa}$ & $63.0 \mathrm{Aa}$ & $57.4 \mathrm{Ab}$ \\
$10-20$ & $17.5 \mathrm{Ba}$ & $19.0 \mathrm{Ba}$ & $17.0 \mathrm{Ba}$ & $20.6 \mathrm{Ba}$ \\
$20-30$ & $10.9 \mathrm{BCa}$ & $9.2 \mathrm{BCa}$ & $11.1 \mathrm{Ba}$ & $13.9 \mathrm{BCa}$ \\
$30-40$ & $6.1 \mathrm{Ca}$ & $6.9 \mathrm{Ca}$ & $8.9 \mathrm{Ba}$ & $8.1 \mathrm{Ca}$ \\
\hline & \multicolumn{5}{c}{ Fall 2013} \\
$0-10$ & $51.8 \mathrm{Ab}$ & $61.1 \mathrm{Aa}$ & $58.0 \mathrm{Aa}$ & $60.0 \mathrm{Aab}$ \\
$10-20$ & $21.9 \mathrm{Ba}$ & $19.0 \mathrm{Ba}$ & $23.5 \mathrm{Ba}$ & $21.7 \mathrm{Ba}$ \\
$20-30$ & $15.2 \mathrm{Ba}$ & $11.0 \mathrm{Ba}$ & $11.0 \mathrm{Ca}$ & $11.1 \mathrm{BCa}$ \\
$30-40$ & $11.2 \mathrm{Ba}$ & $8.9 \mathrm{Ba}$ & $7.5 \mathrm{Ca}$ & $7.2 \mathrm{Ca}$ \\
\hline
\end{tabular}

${ }^{(1)}$ Means followed by equal letters, uppercase in the rows and lowercase letters in the columns, do not differ significantly in the same season by Bonferroni's test, at 5\% probability. with Arachis pintoi, with an RDM density of $62 \%$ observed at a depth of 0-15 cm; Sarmento et al. (2008) also obtained an RDM density of $62 \%$ at a depth of $0-10 \mathrm{~cm}$, in Milênio grass pastures. After 7 years of planting $U$. brizantha, Santos et al. (2007) found that the RDM planting density decreased with depth, resulting in an RDM density of $67 \%$ at $10 \mathrm{~cm}$ and $11 \%$ at $40 \mathrm{~cm}$.

Among the grazing strategies within a season, a significant effect was observed only in the 0-10-cm layer with the 90-20 strategy, resulting in a concentration of a greater proportion of the roots in this layer in summer (65.6\%) than in fall $(51.8 \%)$, whereas with the 95-30 strategy, these RDM densities were $65.5 \%$ in spring and $57.4 \%$ in summer (Table 7 ). These results indicate that after a period of favorable growth with a positive water balance, there was a faster regeneration of the root system; this was followed by an increase in the disappearance or turnover of roots, which was likely to affect the oldest roots.

For the less severe grazing treatments $(95 \% \mathrm{LI})$, in winter (Figure $1 \mathrm{~A}$ ) and in spring (Figure $1 \mathrm{~B}$ ), there was a higher concentration of roots near the surface for the 95-30 treatment than the 95-20 treatment. The similar RDM densities observed between the 95\% LI grazing strategies in winter $\left(0.76\right.$ versus $\left.0.60 \mathrm{~g} \mathrm{dm}^{-3}\right)$ and spring (1.60 versus $1.67 \mathrm{~g} \mathrm{dm}^{-3}$ ) (Table 5), indicating the maintenance of a greater proportion of roots in the soil surface layer. This result suggests that the root system has less need to go deeper to acquire water and nutrients when grazing is less severe.

In summer, there was a higher concentration of roots near the surface for the more severe grazing treatments (90-20) than the less severe ones (95-30) (Figure $1 \mathrm{C}$ ). Although similar RDM densities (1.48 versus $1.26 \mathrm{~g} \mathrm{dm}^{-3}$ ) were observed in summer with these treatments, the lowest PD was obtained with less severe grazing (95-30); this is likely associated with the renewal of the root system, also known as "turnover", during the favorable summer growth period and with the accumulation of organic reserves. Notably, although there were no differences between the RDM density with the 95-30 treatment between spring and summer (1.67 versus $1.26 \mathrm{~g} \mathrm{dm}^{-3}$, respectively; Table 6), the PD in the superficial layer was higher in spring than in summer (65.5 versus $57.4 \%$, respectively) as shown in Table 7. 

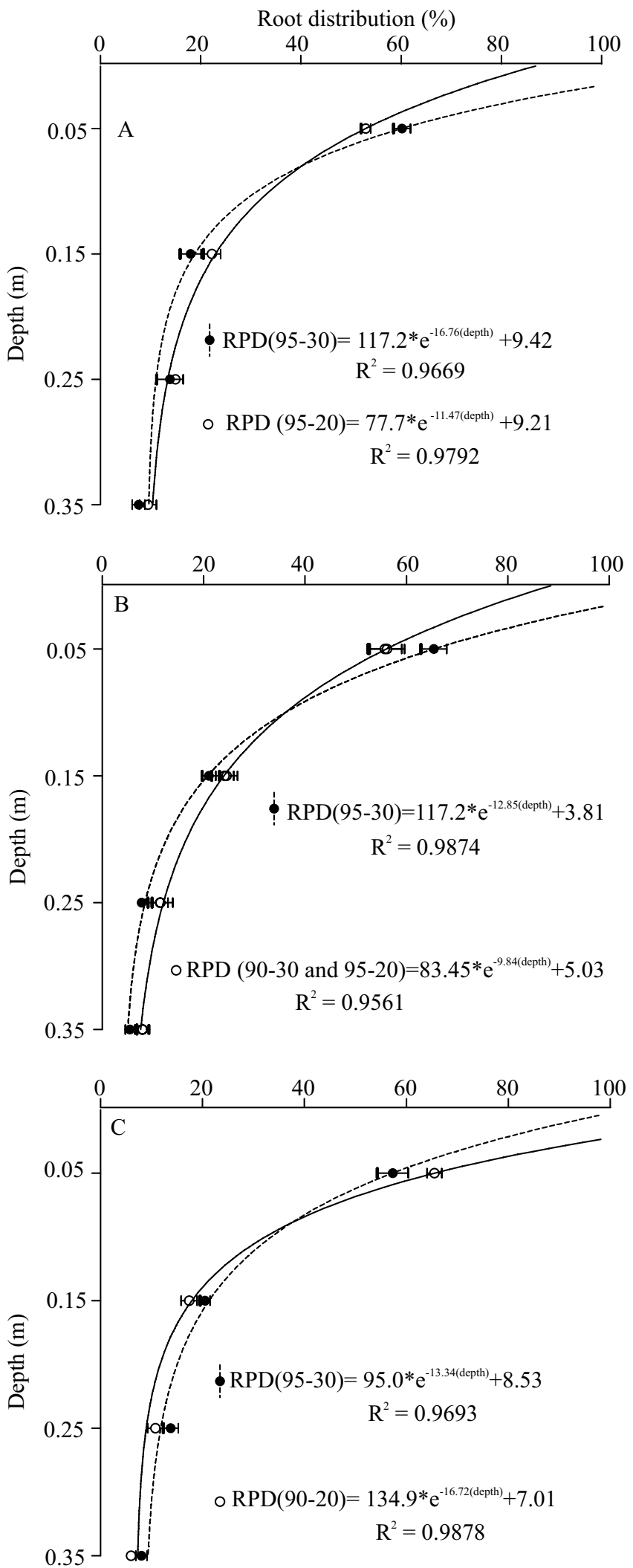

Figure 1. Root percentage distribution of Florico grass (Cynodon nlemfuensis): A, winter 2012; B, spring 2012; and C, summer 2013.

\section{Conclusions}

1. The combination of light interception with post-grazing residue is not an efficient parameter to determine optimal Florico grass (Cynodon nlemfuensis) grazing strategy.

2. Lower densities of root dry matter mass occur in winter, rather than in the other seasons, regardless of the grazing strategy.

3. In spring, the grazing strategies affect both root dry matter mass density and root depth percentage distribution.

4. Regardless of the grazing strategy, between 52 and $66 \%$ of the root dry matter mass density is concentrated in the $0-10-\mathrm{cm}$ soil layer, with $17-25 \%$ found in the 10-20-cm layer.

5. The parameters of the aerial part of the plant are not positively associated with the root dry matter mass density.

\section{Acknowledgments}

To Coordenação de Aperfeiçoamento de Pessoal de Nível Superior (Capes), for the scholarships granted to the first author; to Fundação Carlos Chagas Filho de Amparo à Pesquisa do Estado do Rio de Janeiro (Faperj), for providing financial support for the project; and to Pesquisa Agropecuária do Estado do Rio de Janeiro (Pesagro-Rio), for providing staff and infrastructure for performing the experiment.

\section{References}

BARBOSA, R.A.; NASCIMENTO JÚNIOR, D. do; EUCLIDES, V.P.B.; SILVA, S.C.; ZIMMER, A.H.; TORRES JÚNIOR, R.A.A. Capim-tanzânia submetido a combinações entre intensidade e frequência de pastejo. Pesquisa Agropecuária Brasileira, v.42, p.329-340, 2007. DOI: 10.1590/S0100-204X2007000300005.

BRAGA, G.J.; PEDREIRA, C.G.S.; HERLING, V.R.; LUZ, P.H. de C.; LIMA, C.G. de. Sward structure and herbage yield of rotationally stocked pastures of 'Marandu' palisadegrass [Brachiaria brizantha (A. Rich.) Stapf] as affected by herbage allowance. Scientia Agricola, v.63, p.121-129, 2006. DOI: 10.1590/S0103-90162006000200003.

CAMARGO FILHO, S.T. Morfologia radicular de quatro gramíneas forrageiras e sua relação com a aquisição de nutrientes e produção de fitomassa. 2007.99p. Tese (Doutorado) - Universidade Federal Rural do Rio de Janeiro, Seropédica.

CARNEVALLI, R.A.; SILVA, S.C. Validação de técnicas experimentais para avaliação de características agronômicas e ecológicas de pastagens de Cynodon dactylon cv. Coastcross-1. 
Scientia Agricola, v.56, p.489-499, 1999. DOI: 10.1590/S010390161999000200032.

CARNEVALLI, R.A.; SILVA, S.C.; BUENO, A.A.O.; UEBELE, M.C.; BUENO, F.O.; HODGSON, J.; SILVA, G.N.; MORAIS, J.P.G. Herbage production and grazing losses in Panicum maximum cv. Mombaça under four grazing managements. Tropical Grasslands, v.40, p.165-176, 2006.

CARVALHO, M.S.S.; PEDREIRA, C.G.S.; TONATO, F. Análise de crescimento de capins do gênero Cynodon submetidos a frequências de colheita. Boletim da Indústria Animal, v.69, p.041-049, 2012.

COSTA, C.A.A.; ANDRADE, A.C.; MAGALHÃES, J.A.; MEHL, H.U.; RODRIGUES, B.H.N.; SILVA, E.M. da; BITENCOURT, A.B.; SANTOS, F.J.S.; LUCENA COSTA, N. Características agronômicas dos capins Digitaria sp. e Cynodon dactylon cv. Tifton-85 sob diferentes alturas de resíduo. PubVet, v.7, art. 1509, 2013. DOI: $10.22256 /$ pubvet.v7n5.1510.

COSTA, F. da; PEREYRA, R.O.; PACIORNIK, S.; ABREU, J.B.R. de. Distribuição vertical das características morfológicas do sistema radicular de Brachiaria humidicola. Pasturas Tropicales, v.24, p.14-20, 2002.

CUNHA, F.F. da; RAMOS, M.M.; ALENCAR, C.A.B. de; MARTINS, C.E.; CÓSER, A.C.; OLIVEIRA, R.A. de. Sistema radicular de seis gramíneas irrigadas em diferentes adubações nitrogenadas e manejos. Acta Scientiarum. Agronomy, v.32, p.351-357, 2010. DOI: 10.4025/actasciagron.v32i2.1020.

INMET. Instituto Nacional de Meteorologia. Estações e Dados: RJ - Seropédica - Ecologia Agrícola. Available at: <http://www. inmet.gov.br/portal/index.php? $r=$ estacoes/estacoesAutomaticas>. Accessed on: Aug. 292017.

KAISER, D.R.; REINERT, D.J.; REICHERT, J.M.; COLLARES, G.L.; KUNZ, M. Intervalo hídrico ótimo no perfil explorado pelas raízes de feijoeiro em um Latossolo sob diferentes níveis de compactação. Revista Brasileira de Ciência do Solo, v.33, p.845-855, 2009. DOI: 10.1590/S0100-06832009000400009.

MONTEIRO, F.A.; CONSOLMAGNO NETO, D. Sistema radicular do capim-tanzânia adubado com potássio e magnésio. Revista Brasileira de Zootecnia, v.37, p.810-818, 2008. DOI: 10.1590/S1516-35982008000500005.

MUELLER, K.E.; TILMAN, D.; FORNARA, D.A.; HOBBIE, S.E. Root depth distribution and the diversity-productivity relationship in a long-term grassland experiment. Ecology, v.94, p.787-793, 2013. DOI: 10.1890/12-1399.1.

PEDREIRA, B.C. e; PEDREIRA, C.G.S.; SILVA, S.C. da. Estrutura do dossel e acúmulo de forragem de Brachiaria brizantha cultivar Xaraés em resposta a estratégias de pastejo. Pesquisa Agropecuária Brasileira, v.42, p.281-287, 2007. DOI: 10.1590/S0100-204X2007000200018.

PEDREIRA, C.G.S. Gênero Cynodon. In: FONSECA, D.M. da; MARTUSCELlO, J.A. (Ed.). Plantas Forrageiras. Viçosa: Ed. da UFV, 2010. p.78-130.

PLAZA-BONILlA, D.; ÁlVARO-FUENTES, J.; HANSEN, N.C.; LAMPURLANÉS, J.; CANTERO-MARTÍNEZ, C. Winter cereal root growth and aboveground-belowground biomass ratios as affected by site and tillage system in dryland Mediterranean conditions. Plant Soil, v.374, p.925-939, 2014. DOI: 10.1007/ s11104-013-1926-3.

RIBEIRO, O.L.; CECATO, U.; RODRIGUES, A.M.; FAVERI, J.C.; JOBIM, C.C.; LUGÃO, S.M.B. Biomassa radicular e reservas orgânicas em coastcross consorciada ou não com Arachis pintoi, com e sem nitrogênio, sob pastejo. Revista Brasileira de Saúde e Produção Animal, v.12, p.318-328, 2011.

RODRIGUES FILHO, J.A.; AZEVEDO, G.P.C. de; CAMARÃO, A.P.; COSTA, P.A. da. Produção de forragem e valor nutritivo do capim-estrela (Cynodon nlemfuensis Vanderyst) em três idades de corte. Pasturas Tropicales, v.22, p.28-34, 2000.

RODRIGUES, R.C.; MOURÃO, G.B.; VALINOTE, A.C.; HERLING, V.R. Reservas orgânicas, relação parte aérea-raiz e c-n e eliminação do meristema apical no capim-xaraés sob doses de nitrogênio e potássio. Ciência Animal Brasileira, v.8, p.505$514,2007$.

SANTOS, H.G. dos; JACOMINE, P.K.T.; ANJOS, L.H.C. dos; OLIVEIRA, V.A. de; LUMBRERAS, J.F.; COELHO, M.R.; ALMEIDA, J.A. de; CUNHA, T.J.F.; OLIVEIRA, J.B. de. Sistema brasileiro de classificação de solos. 3.ed. rev. e ampl. Brasília: Embrapa, 2013. 353p.

SANTOS, R.S.M. dos; OLIVEIRA, I.P. de; MORAIS, R.F. de; URQUIAGA, S.C.; BODDEY, R.M.; ALVES, B.J.R. Componentes da parte aérea e raízes de pastagens de Brachiaria spp. em diferentes idades após a reforma, como indicadores de produtividade em ambiente de Cerrado. Pesquisa Agropecuária Tropical, v.37, p.119-124, 2007.

SARMENTO, P.; RODRIGUES, L.R. de A.; LUGÃO, S.M.B.; CRUZ, M.C.P. da; CAMPOS, F.P. de; FERREIRA, M.E.; OLIVEIRA, R.F. de. Sistema radicular do Panicum maximum Jacq. cv. IPR-86 Milênio adubado com nitrogênio e submetido à lotação rotacionada. Revista Brasileira de Zootecnia, v.37, p.27-34, 2008.

SILVA, L.V. da; CÂNDIDO, M.J.D.; PESSOA, J.P.M.; CAVALCANTE, A.C.R.; CARNEIRO, M.S. de S.; SILVA, A. do N. Componentes da biomassa e características estruturais em capimaruana sob diferentes frequências e intensidades de desfolhação.

Pesquisa Agropecuária Brasileira, v.50, p.1192-1200, 2015. DOI: 10.1590/S0100-204X2015001200009.

SILVEIRA, C.P.; MONTEIRO, F.A. Influência da adubação com nitrogênio e cálcio nas características morfológicas e produtivas das raízes de capim-tanzânia cultivado em solução nutritiva. Revista Brasileira de Zootecnia, v.40, p.47-52, 2011. DOI: 10.1590/S1516-35982011000100007.

SORIANO, V. de S.; KOZLOSKI, G.V.; QUADROS, F.L.F. de; PIRES, C.C.; GRIEBLER, L. Produção animal e vegetal em pastagem de Cynodon manejada sob diferentes ofertas de forragem por ovinos de dois grupos genéticos. Ciência Rural, v.43, p.139-144, 2013. DOI: 10.1590/S0103-84782012005000149.

VILELA, D.; PAIVA, P.C. de A.; LIMA, J.A. de; CARDOSO, R.C. de. Morfogênese e acúmulo de forragem em pastagem de Cynodon dactylon cv. coastcross em diferentes estações de crescimento. Revista Brasileira de Zootecnia, v.34, p.1891-1896, 2005. DOI: $10.1590 /$ S1516-35982005000600012. 
ZANINE, A. de M.; NASCIMENTO JÚNIOR, D. do; SANTOS, M.E.R.; PENA, K. da S.; SILVA, S.C. da; SBRISSIA, A.F. Características estruturais e acúmulo de forragem em capim-tanzânia sob pastejo rotativo. Revista Brasileira de Zootecnia, v.40, p.2364-2373, 2011. DOI: 10.1590/S151635982011001100012 .

Received on July 19, 2016 and accepted on March 6, 2017 